\title{
O SITIANTE TRADICIONAL E A PERCEPÇÃo DO ESPAÇO (1)
}

\author{
Maria ISAURA PEReIRA DE QUEIROZ
}

Georges Gurvitch, em seu constante desejo de abrir novas vias à pesquisa empirica e à reflexão sociológica, havia orientado um de seus ûltimos cursos para o estudo da percepção do espaço e da extensão, associando-a aos diferentes quadros de referência sociais em que se efetua (2). Da mesma forma que os individuos, as coletividades, os grupos e as sociedades globais funcionam como "centros dos estados mentais denominados percepçōes", assim, toda percepção, inclusive a dos espaços, faz parte de nossa existencia tanto coletiva quanto individual e não poderá ser desta separada (3). Gurvitch distingue o "espaço" que é extensão não quantificada, da "extensão" em que o espaço se transforma pela quantificação; também distingue "espaços sociais" e "espaços do mundo exterior". Malgrado esta diferenciação, considera o espaço como único; a diversidade sob a qual se apresenta não é realidade plena, e sim resultado das várias perspectivas em que se efetuam diferentes tomadas de consciência. Estas não são ilusórias; constituem vias de aproximação em relação ao espaço real e único. Espaços sociais e espaços do mundo exterior permanecem também inseparavelmente ligados à percepção que deles se tem (4).

O grande interesse do curso do qual participamos, as discussōes que se travaram com respeito às definiçōes e aos problemas relativos à variedade das percepçōes coletivas, levaram-nos a estudar a percepçāo do sitiante tra-

(1) Artigo publlcado em llvro editado na Franca, como homenagem a memoria de Georges Gurvitch, 1968.

(2) Curso dado em 1963-1964, Ecole Pratique des Hautes rtudes, VI.a Secçá,

(3) Gurvitch, 1964, pp. 79-80.

(4) Gurvitch, 1964, p. 80. 
dicional (5) com relação ao espaço geográfico e social dentro do qual vive. Qual a noção que dele se formula? Como constrói tal noção? Por que meios? Prestando homenagem a Georges Gurvitch, cuja influência sobre nosso conhecimento sociológico foi profunda e de quem recebemos preciosas mostras de amizade, quisemos percorrer com ele um dos últimos caminhos que abriu à pesquisa em nossa especialidade.

O Brasil agrário é conhecido principalmente como país de grandes monoculturas. Os pequenos lavradores, que vivem do produto da policultura de subsistência, são todavia numerosos. Enquanto as grandes monoculturas de exportaçăo não cobriam senão quatro milhōes de hectares em 1950, as pequenas culturas de subsistência se estendiam pelo menos por quatorze milhōes de hectares, no pais (6). As roças são encontradas em plena expansão principalmente em zonas ainda não invadidas nem pela grande monocultura de exportação, nem pela agricultura comercial, e também em zonas que se mantêm distantes da industrializaçāo. E difícil conhecer a quantidade exata desses lavradores, mas é provável que representem mais da metade da mão-de-obra agricola brasileira. Quer sejam proprietários, arrendatários ou parceiros, seu gênero de vida é mais ou menos idêntico e se organizam sempre de modo semelhante. Além disso, a passagem de proprietário a arrendatário ou a parceiro é frequiente e se efetua em geral mais de uma vez durante a vida do lavrador. Pode trabalhar como parceiro durante certo tempo nas terras de um vizinho e voltar a cultivar, um pouco mais tarde, a sua; deixada em descanso durante certo periodo, a terra recobra fertilidade e dá colheitas mais abundantes. O cansaço do solo, cultivado durante largo tempo sem nenhum cuidado; a existência ao lado de sua propriedade, de outra com terras ainda incultas, determinam muitas vezes tal comportamento. Nossa análise, neste artigo, voltar-se-á para esta população de sitiantes tradicionais (7), que apresenta caracteres especificos e que já vimos estudando de algum tempo a esta parte (8).

O sitiante brasileiro habita em suas terras. As casas de uma zona de sítios estão dispersas em torno de pequeno núcleo central, constituído por capela, vendinha, duas ou três habitaçōes, que formam como que a "capital" de um grupo de vizinhança. Os grupos de vizinhança rurais são muito

(5) Adotamos a definicăo de Nice Lecocq Müller: ctodo to pequeno produtor que, responsável pela 1avoura, trabaiha direta e pessoaimente a terra com a ajuda de sua familla e, ocastonalmente, de alguns empregados remuneradoss (1951, pp. 27-28).

(6) Estes dados săo antigos, porém nem sempre é possivel utilizar os do recenseamento de 1960 cujos erros de grande monta năo permitiram a publicacáo integral. Embora ultrapassados, estes dados dão uma nocão clara da grande importancla numérica de tal categorla rural no pais.

(7) 0 sittante tradiclonal brasileiro cabe na categoria dos camponeses definida por Robert Redfleld: está em relaçes de complementaridade com um aglomerado urbano no qual vende o excedente de sua produçán, mas produz primordiaimente para sua subsisténcla (Redfield, 1959).

(8) Perelra de Quelroz, 1958; 1960; 1968 a e b; 1965; 1967. 
homogêneos; a estratificação social é á tênue, tanto mais que os lavradores trabalham a terra quase exclusivamente com o auxilio da família. Trata-se de uma forma de povoamento muito antiga, que remonta aos primeiros tempos da colonização portuguesa. A configuração do grupo de vizinhança e o gênero de suas relaçōes sociais foram e são, por toda a parte, iguais no Brasil, nas zonas onde conseguiram se implantar e se manter, afastados das grandes monoculturas, cujo gênero de vida era diferente. Formam os bairros rurais, apelação que thes é dada em S. Paulo, e que utilizaremos neste trabalho (9).

Os bairros rurais estão muitas vezes separados uns dos outros por grandes distâncias, todavia, quanto mais denso o povoamento da região, mais os bairros se multiplicam e mais as distâncias entre eles diminui. A distância tem grande importância na determinação dos limites de um bairro, pois é preciso que seus membros possam assistir regularmente às festas religiosas celebradas na capela; é preciso também que participem do mutirão, trabalho coletivo que cada lavrador em geral se vê compelido a utilizar. Os habitantes que estão mais próximos do núcleo central têm perfeita consciência de pertencerem ao grupo de vizinhança; os que habitam as fronteiras do mesmo não sabem mais ao certo a que grupo devem-se prender e hesitam entre dois bairros vizinhos. 0 crescimento demográfico multiplica a quantidade dos bairros. Os filhos, ao se casarem, deixam a casa paterna e constroem sua própria habitação um pouco mais longe, sempre nas terras familiares; desbravam o mato e fazem uma roça de subsistência. Formam assim nova célula doméstica e econômica. Se o bairro se torna demasiadamente extenso, um dos componentes pode tomar a decisão de construir nova capela; que se torna centro de convergência para os habitantes demasiadamente afastados da primeira; um novo bairro faz assim sua aparição. $O s$ bairros se multiplicam sempre por cissiparidade.

Todavia, embora ocupando lugar geográfico que se pode determinar com certa precisão, o bairro não está nele implantado de modo imutável. Já no século XIX, os viajantes estrangeiros observavam com espanto a quantidade de capelas em ruinas, de casas abandonadas - taperas - que iam encontrando pelo caminho: seus habitantes haviam partido para se estabelecer em outro local. Tais viajantes concluiram que o bairro era uma unidade social móvel no espaço geográfico brasileiro. Efetivamente, os sitiantes não se implantam profundamente numa área, mesmo quando proprietários; partir não lhes é penoso. Mudam constantemente a localização da roça e da casa, e com a mesma facilidade partem de uma regiāo para outra. Sua pobreza e a rusticidade de suas técnicas foram, muitas vezes, atribuías a esta grande mobilidade (10).

(9) Para a definicão de bairro rural, ver Nice Lecocq Muller, 1951; Antonio Candido, 1964; Pereira de Quelroz, 1967, 1889, para os fins do séc. XIX. 
Muito ao contrário do que se supunha, a técnica agrícola utilizada agricultura de queimadas - exige a mudança constante; é ela uma das causas e năo a consequêencia da mobilidade. $O$ sitiante cultiva uma parcela de suas terras até a exaustão e, em seguida, recomeça um pouco mais longe o mesmo trabalho, no qual emprega instrumentos rudimentares (11); sua casa de pau-a-pique ou de sopapo, coberta de sapé, é fácil de construir e é abandonada sem saudade. A grande extensăo do território nacional constitui, para este gênero de vida, a garantia única de se manter um nivel econômico mais ou menos satisfatório, pois a abundância da colheita depende praticamente do grau de fertilidade do solo. Quando o povoamento de uma zona se torna muito denso, o bairro em geral se fixa, porém o nivel de vida do sitiante paralelamente baixa: cultiva terras "cansadas" e o excedente de produção, que negociava nos povoados e vilas para equilibrar o orçamento, passa a the faltar. Seu nivel de vida se deteriorará rapidamente, se não conseguir desenvolver uma atividade complementar - carvoeiro, oleiro, negociante - ou algum oficio que the traga desafogo (12). Mobilidade no espaço geográfico e possibilidade de adotar atividades complementares constituem, para o sitiante tradicional, condiçōes essenciais para se manter num nivel de vida suportável.

O bairro é um grupo de vizinhança aberto, acolhendo todas as familias que se venham ali estabelecer; nenhum preconceito étnico ou outro impede a integraçăo, que depende principalmente da participação às festas religiosas e do trabalho coletivo. Os inter-casamentos desde muito misturaram os traços étnicos, e os habitantes podem apresentar assim toda a sorte de gradaçōes possiveis da cor da pele. O bairro é sempre uma reuniāo de familias. A familia conjugal é importante unidade econômica, porém é ainda menos sedentária do que o próprio bairro; muda de um lugar para outro com facilidade, as migraçōes regionais sāo, em geral, migraçōes familiares. $\mathrm{O}$ bairro é algumas vezes formado de familias que não têm laços de parentesco entre si, que ali se fixaram ao acaso de suas peregrinaçōes.

Várias familias conjugais provenientes do mesmo tronco comum formam um grupo que se estende verticalmente atravẻs de geraçōes sucessivas, e horizontalmente englobando tias, tios, primos. A familia do sitiante se apresenta como conjugal do ponto de vista econồmico, porém se define como parentela, quando tomamos a perspectiva das relaçōes sociais. A independência econômica e o afastamento no espaço geográfico não ameaçam a solidez dos laços de parentesco. Fortes, duráveis, estes laços são reconhecidos tanto do lado paterno, quanto do lado materno. Observa-se, porém, que os ascendentes nāo são conhecidos com precisāo, seja em se tratando de gente com quem diretamente se teve contacto (os avós), sejam os que se conhece por

(11) Segundo o recenseamento de 1960, o Brasil contava 2.994 .093 médlas infequenas exploracós agricolas, porém apenas 1.031 .930 arados e um número

(12) Perelra de Quelroz: e Garcia Fukul, 1968. 
tradição oral. Para além dos tempos vividos pelos velhos do bairro, as noçōes se tornam ainda mais vagas e fluidas ("faz muito tempo". "é coisa muito velha") e o contorno do grupo de parentela se torna impreciso (13). O afastamento geográfico não pesa sobre as relaçōes familiares; mesmo tornando-se indiretas ou quase, persistem. Os que partiram conservam os mesmos direitos, quer retornem, quer nāo e seus filhos poderão reclamar, mais tarde, o apoio que lhes deve a familia da qual se afastaram seus pais. A parentela tem por dever a ajuda mútua; a reciprocidade é elemento fundamental destas relaçōes. O casamento cria relaçōes de aliança que possuem idêntico valor e que acarretam também obrigaçōes reciprocas.

O compadrio segue o mesmo principio. O padrinho está ligado ao pai e à māe de seu afilhado, do mesmo modo que a este; alẻm disso, uma ligação de parentesco se estabelece entre o padrinho e a madrinha de um mesmo afilhado, constituindo todo o conjunto um grupo de compadres (14). Existem também maneiras variadas de se estabelecer laços de compadrio além do batismo: compadres da fogueira ou de S. Joăo, padrinhos da Semana Santa, constituem laços estabelecidos entre individuos que voluntariamente desejaram-se unir por meio deles. Num bairro composto de familias sem outros laços senão os de vizinhança, o compadrio torna-se fator decisivo de integração social. Os recém-chegados não se sentem verdadeiramente membros do bairro senão a partir do momento em que são familiarmente chamados de "compadres". Assim, não é dificil ir viver noutra regiāo; basta encontrar ali um bairro em que a familia possa se integrar. As diversas formas de compadrio permitirāo estabelecer laços duráveis com as famílias que já o compōem. Quando alguém decide regressar ao local de origem, ali encontra sempre um parente que tem a obrigaçāo de o receber e ajudar. 0 perigo do isolamento torna-se assim praticamente inexistente para o sitiante tradicional. $O$ bairro näo se caracteriza por sua imobilidade geográfica, porém também não se define como uma reunião permanente dos mesmos grupos familiares. Sua composiçāo interna se modifica, as familias que o formam variam no decorrer dos anos e das geraçōes; apesar disso, constitui uma estrutura consistente e durável, que as enquadra.

Diferenças de fortuna existem no interior dos bairros, mas não se traduzem por uma estratificaçāo social muito visivel; o aparecimento desta sinal de uma transformação profunda ou, mesmo, da destruição do bairro. No bairro tradicional (15), o sitiante proprietário e o não-proprietário se

(13) O casamento civil é o único válido entre nos. Todavia, o sitiante tradicional em geral desconhece as formalldades legais: casamento clvil, registro de filhos, atestados de óbito. Năo pode reallzar as formalidades rellglosas, a nāo ser que exista um padre pela redondeza, o que nem sempre se dá. E, pois, dificil estudar as geracóes em sua continuidade, pols os documentos legais săo inexistentes. (14) ver outras formas e funcőes de compadrio em Pereira de Quelroz, 1957; e relacōes intra-famillares em Garcia Fukui, 1969.

(15) Se falamos em ebairro tradicional, e esitlante tradicionals, e porque já. tivemos ocaslăo de estudar formas mais recentes que sẳo divergentes. Perelra. de Quelroz, 1967. 
situam no mesmo nivel; seu gênero de vida é idêntico; as aspiraçöes, as necessidades, o consumo são semelhantes. Ao penetrar na habitação de um sitiante tradicional, não se sabe nunca se se trata de um proprietário ou não, se é abastado ou não, tal a similaridade da maneira de viver. O inter-casamento entre proprietários e não-proprietários é comum; suas posiçōes reciprocas se tornam mais próximas ainda por meio do compadrio. $\mathrm{O}$ bairro é assim um grupo social de tendência igualitária.

As únicas diferenças sociais que claramente se delineiam são devidas à variação do prestigio de que gozam os individuos. A riqueza pode aumentar o prestigio mas não é causa direta deste, que depende de qualidades ressoais positivamente sancionadas pela tradição: desinteresse, generosidade, respeito pelos outros, bondade, coragem, bom senso e, em último lugar, instrução. Quanto mais o individuo der provas destas qualidades, mais sua autoridade aumenta no bairro, mais sua voz e ouvida nas deliberaçōes tomadas em comum, mais é procurado para conselheiro, mais é convidado para padrinho das crianças. Quando desaparece, aquele que possui qualidades análogas naturalmente the toma o lugar.

A existência do bairro é ritmada por momentos de reuniāo e de dispersão de seus membros, em função do trabalho agrícola e do lazer. 0 sitiante cultiva suas terras com a familia; conhece, todavia, certas formas de trabalho coletivo, sendo a principal delas o mutirão (16). Quando se quer desempenhar rapidamente e a contento uma tarefa determinada, pede-se o auxilio dos vizinhos; desbravamento, semeadura, colheita podem assim constituir o pretexto para uma convocação que reune a vizinhança. Quem convoca tem a obrigação moral de responder aos apelos que the forem em seguida lançados, sob pena de ser posto à margem pelo grupo. Deve também fornecer a alimentaçāo durante as jornadas de trabalho; se é pobre, cada qual trará sua marmita e o sitiante oferecerá apenas uma refeição simbólica - um café com bolinhos, por exemplo.

O mutirăo toma em geral aspectos festivos. Os sitiantes chegam acompanhados pela familia; os homens vão trabalhar na roça, as mulheres se encarregam da cozinha. A noite, reúnem-se todos para jantar e a festa começa: cantigas, danças, desafios etc. A funçāo social do mutirão é patente: é um fator de reuniāo e, assim, reforça a coesāo social. O mutirāo dá também ao sitiante o sentimento das fronteiras geográficas do bairro e de suas divisōes internas. Para responder ao apelo dos vizinhos, é obrigado a percorrer o bairro em todos os sentidos; se desinteligências existem entre os habitantes, sabe por quem será convidado e por quem não o será. Adquire assim a noçāo do conjunto do grupo de vizinhança e a noção de sua posição social nos diversos sub-grupos. O mutirāo permite também um trabalho agri-

(16) O trabalho rural coletivo recebe nomes diversos conforme as regibes; utilizamos o de emutirăos, que parece ser o mais difundido. 
cola muito mais rápido, assim como o cultivo de uma extensäo maior de terreno, porém sua realização depende da harmonia interna do grupo de vizinhança. Que uma disputa venha a explodir entre algumas familias, e o mutirāo fica ameaçado; se a fragmentação interna do bairro não é muito profunda, os sub-grupos podem ainda se reunir e procuram salvaguardar o antigo costume, havendo a separação clássica - quem é aliado ou parente de um sub-grupo nāo comparece ao mutirāo do outro. Caso contrário, o mutirāo desaparece e o nivel de vida do sitiante sofre uma reduçāo patente, já que as parcelas cultivadas se tornam muitos menores (17).

O mutirão desempenha também importante função no que diz respeito à integração do bairro na vida da regiāo. Com efeito, o excedente da produçāo permite ao sitiante abastecer os povoados e vilas vizinhos, onde vende as sobras da colheita e adquire os objetos que não fabrica (18). Deve renunciar a tudo isto se as colheitas são pouco importantes. Estando seu consumo tradicionalmente determinado, poucos objetos despertam-lhe o desejo; os artesãos do grupo de vizinhança the fornecem a maior parte dos instrumentos e objetos de que necessita. Na vila, adquire cortes de fazenda para a muIher e a filha, roupas de brim barato para ele mesmo e o filho, bugigangas: Porém, que lhe falte o excedente de produção, e deve se abster destas compras, que passam a constituir "luxo", quando antes eram objetos de necessidade. E quando a pobreza é muita, andrajoso, não participa mais das festas e das reuniöes do grupo, premido por um sentimento de vergonha de sua indumentária (19).

Todavia, se freqüenta as feiras da regiāo e nelas efetua suas modestas transaçōes, manifesta também certo orgulho pela sua independência com relação à cidade ou à vila, experimenta certo sentimento de superioridade decorrente do fato de que os citadinos dependem dele: onde comprariam feijão, milho, mandioca, rapadura, se deixasse de os produzir? Revolta-se quando sente que é tratado com pouco caso e procura então guardar distância. 0 fato de freqüentar vilas e cidades dá ao sitiante tradicional o conhecimento de um gênero de vida diferente do seu, o gênero de vida citadino. Aprende assim que o mundo é composto de uma parte que o toca de perto, formada por grupos de vizinhança semelhantes ao seu, compondo todo o conjunto do mundo rural; a outra parte, ao contrário, lhe é inteiramente estranha e forma o mundo citadino.

(17) Ver, para a decadência do mutırăo, Perelra de Queiroz e Garcla Fukul, 1968; Pereira de Queiroz, 1960, 1963 a e 1963 b.

(18) A industrializacão está transformando rapidamente o consumo dos stt'antes tradicionais. Feiras e mercados estão atualmente inundados por objetos de matérla plástica, que apreclam muitissimo. Todavia, estas despesas suplementares materia plastica, que apreciam muitissimo. Todavia, estas despesas suplementares 1964; Perelra de Quelroz, 1960 .
(19) Lia Garcla Fukul póde ver de perto esta decadencla entre os sitlantes do Sertăo de Juquitiba, a $70 \mathrm{kms}$. da capital de S. Paulo. Ver Perelra de Queiroz e Garcia Fukui, 1968. 
As festas religiosas dăo ao sitiante uma noção ainda mais vigorosa de que pertencem a um bairro. O catolicismo dos sitiantes tradicionais está centralizado pelo culto dos santos. Cada bairro, cada família, possui um padroeiro da sua devoção, que é necessário cultuar a fim de receber em troca a proteção indispensável. Todos os habitantes do bairro devem participar das festas, a capela é um verdadeiro centro de interesses. Além da festa do padroeiro do bairro, outras se escalonam no decorrer do ano: festa de Reis, Semana Santa, festa de Santa Cruz, festas juninas, festa do Divino. Organizam-se entre os bairros de maneira a permitir também a participaçāo dos moradores de bairros vizinhos. Assim, se dois bairros têm Sant'Ana por padroeira, um a festejará no dia 20 de julho, o outro no dia 27. A festa reúne, pois, uma quantidade de familias maior do que a que forma um grupo de vizinhança.

As cerimônias são organizadas por um festeiro, que é como que o "dono" da festa, sorteado cada ano entre os chefes de família; em princípio, é ele quem paga as despesas. Como esta ultrapassa sempre os recursos de qualquer sitiante, todos os anos a contribuição de todos é recolhida por pequenos grupos especificos, dos quais o mais conhecido é a Folia do Divino. Tais grupos se compöem de músicos (dois ou três) e de um indivíduo que carrega a bandeira do santo; percorrem os arredores cantando e tocando, sendo hospedados nos sítios onde comparecem. O caminho percorrido retraça os contornos do bairro. Com suas oferendas, as familias marcam a integraçāo a ele: uma galinha, um leitāozinho, espigas de milho, um saco de farinha de mandioca, de que se privam em favor da festa coletiva. Nada ofertar significa querer ficar à margem do grupo; a participaçāo econômica, muito mais do que a presença à festa, marca o fato de se pertencer ao bairro (20).

A festa pode durar de dois dias a uma semana; os participantes executam em comum certas tarefas (construção de ranchos, abate de animais, para as refeiçōes, corte de árvores para lenha), assim como ritos religiosos (procissōes, novenas, ladainhas). Na última noite procede-se ao leilão de prendas, rifando-se tudo quanto foi ofertado para esse fim; o produto do leilão serve para compensar o festeiro de suas despesas. Nas festas há também desafios e danças populares. E raro que sejam tais comemoraçōes dirigidas por um padre; os padres foram sempre pouco numerosos no Brasil e os habitantes do meio rural se acostumaram a não contar com eles. O festeiro pode convidar um para participar da festa, porém como convidado. Assim, o bairro que é uma entidade independente do ponto de vista econômico, o é também do ponto de vista religioso. O padre sendo em geral um habitante da cidade, o paralelismo entre esta e o bairro rural novamente se afirma; o padre é um visitante citadino que năo se integra no grupo de

(20) O protestantismo comeca a se inflitrar no melo rural braslleiro, porém as ramillas protestantes de um bairro também dăo eesmolass a Folla e participam das que pertencem. 
vizinhança. As grandes festas religiosas são, por outro lado, o momento em que o bairro rural se abre para o exterior: gente de fora, quer sejam sitiantes de outros bairros, quer sejam citadinos como o padre, delas participam. Assim, os sitiantes tomam de novo consciência de que pertencem a um mundo que ultrapassa seu grupo de vizinhança e que é formado de um lado pelo conjunto de grupos de sitiantes existentes na região, e de outro lado pelo
povoado ou pela cidade.

Cada familia também comemora seu santo padroeiro organizando novenas em sua honra; a imagem está entronizada no oratório doméstico, enfeitado de flores de papel e de estrelas prateadas. E a ela que se pede auxilio e proteção na vida cotidiana. Os vizinhos sāo convidados a participar da novena dirigida por um rezador (21); terminada a reza, toma-se café com bolinhos. Do mesmo modo que o mutirão, as novenas familiares são delimitadas, em seus participantes, pelas divisões internas do grupo de vizinhança: nāo são cconvidados aqueles com quem se está brigado. Durante a novena, reúnem-se a parentela, os afins, os amigos.

Na vida dos sitiantes tradicionais, a religiāo não age apenas como fator de concentração, porém também como fator de dispersão, pois as romarias aos lugares considerados santificados são organizadas no decorrer do ano. Os sitiantes partem em grupos de famílias; os que ficam, tomam conta da criação dos que partem, e a ajuda mútua facilita como sempre a mobilidade. Os centros de peregrinação tendem a se tornar pequenas capitais regionais do mundo rural tradicional. Frequentando-os, o sitiante toma consciência da amplitude de seu universo, pois encontra ai outros sitiantes semelhantes a ele, provenientes de regiōes até muito distantes.

A idéia que o sitiante forma a respeito dos santos é também de tipo familiar; o santo não é um ser longínquo, impessoal, invisivel; sob a forma da imagem, habita o oratório ou a capela. A imagem não é um símbolo, ela é o próprio santo (22); o santo pertence ao mundo natural pela representação que está no altar e ao mundo sobrenatural por sua essência. Como participa do mundo natural, é possivel agir sobre ele por intermédio da imagem; ladainhas são cantadas para agradá-lo ou para conseguir graças, ou para agradecer os dons recebidos; quando nāo atende aos pedidos dos fiéis, é escondido atrás da porta, é colocado de cabeça para baixo, é castigado enfim. A relação padrinho-afilhado exprime de maneira justa a ligação entre o santo e seu devoto. Assim como o afilhado deve regularmente visitar o padrinho e pedir-lhe a bênção, o devoto deve honrar seu padrinho celeste ofer-

(21) O rezador é um personagem que conhece oracoes e ladainhas; dirige as procissరes, as novenas e as práticas religlosas em geral. Toma o lugar do padre, quase sempre ausente do melo rural tradlcional, no Brasil.

(22) Assim se expllica a recusa geral em trocar as imagens ingenuamente felas, grosseiras, toscas, por outras novas e vistosas fabricadas na cidade: a nova imagem terá as mesmas virtudes da antiga? Năo é certo, já que năo se trata mais da mesma. Pols dois irmăos gemeos năo săo muitas vezes tăo diferentes? 
tando-lhe regularmente velas e novenas pelo menos; espera, em contrapartida, o auxilio dele nos momentos dificeis, do mesmo modo que o afilhado conta com seu padrinho. A reciprocidade domina as relaçōes entre o santo e seus fiēis.

Acredita-se que os santos intervenham na vida quotidiana; estāo sempre presentes, prontos a auxiliar ou a impedir as atividades dos fiéis. Cada santo tem suas peculiaridades; alguns são mais caprichosos do que outros, porém todos manifestam mudanças de humor imprevisiveis. $O$ sitiante tradicional espera também deles a proteção após a morte: o santo padroeiro deve olhar pela familia dos seus devotos, arranjando-se um bom lugar no paraíso, próximo ao que ocupa. O paraiso é composto de grupos de familias reunidas em torno de seu patrono especifico e localizadas próximas ao padroeiro do bairro. Chegando ao céu, o sitiante encontra-se num ambiente que the é conhecido, no meio de parentes e vizinhos; nenhuma surpresa, tratase de uma mudança que se assemelha à migração para outro grupo de vizinhança. As almas dos mortos, embora integradas no mundo sobrenatural, regressam de bom grado para fazer visitas à familia, aparecendo em sonho a parentes e amigos. Também auxiliam a parentela, e esta lhes deve, em troca, ritos funerários, - as danças de S. Gonçalo, por exemplo, ou as "penitências" que thes facilitarăo a passagem pelo purgatório (23).

As relaçōes que se estabelecem entre o mundo natural e o sobrenatural são, pois, do mesmo tipo que as relaçōes familiares e de vizinhança. Seu princípio fundamental é o mesmo que domina as relaçōes sociais tradicionais: de $u t$ des, em que a noçáo de reciprocidade é predominante. Os mesmos comportamentos emocionais estão também presentes nos dois tipos de relaçōes: o sitiante tradicional, ligando-se a um padroeiro, tem para com este a mesma afeição, a mesma ternura, a mesma zanga, a mesma brabeza que manifesta nas relaçōes familiares. Pode-se dizer que a parentela do sitiante tradicional se divide em duas partes, uma situada no mundo profano e a outra no mundo sobrenatural, esta composta pelos mortos da familia egrupados em torno do padroeiro.

A separação entre natural e sobrenatural é assim inteiramente fluida, - sobrenatural constituindo uma extensāo do mundo profano. 0 mundo natural se compōe de múltiplos bairros, e com eles o sitiante não entra em contacto senão em circunstâncias bem determinadas; o mundo sobrenatural tem também seus bairros, com os quais o sitiante pode estabelecer relaçōes mediante certos ritos e certos comportamentos. Num pais em que as distâncias geográficas afastam desmedidamente os habitantes, a distinçāo entre natural e sobrenatural perde toda a importância; torna-se tāo vaga quanto a extensăo geográfica em que se dispersam as familias e os bairros. Por outro lado, a interpenetraçăo entre sagrado e profano forma a própria essên-

(23) Perelra de Quelroz, 1958, 1961. 
cia da ordem natural: toda planta é ao mesmo tempo inofensiva e mágica; todo gesto é ao mesmo tempo bom e mau. Os limites entre pecado e virtude são precários e é possivel atingir a extrema santidade pelo caminho dos piores vícios (24). A ordem natural das coisas compöe-se de um pouco de tudo; vai do melhor ao pior, do sagrado ao profano, sem linha de demarcação; tudo está reunido num só e mesmo sistema, que não pode deixar então de ser ambiguo e ambivalente.

Os individuos, porém, não conhecem senão parcialmente este universo multiforme. Nunca se sabe tudo; elementos desconhecidos e imponderáveis interferem na mais banal das atividades e a podem transtornar completamente. A doença interrompe bruscamente o curso da vida; a seca sobrevem quando tudo fazia prever a chuva, e assim por diante. Algumas pessoas possuem todavia o dom de penetrar mais longe no segredo das coisas e podem revelar os erros cometidos pelo vulgo ao lidar com elas: curandeiros, feiticeiros, taumaturgos. Seu saber é sempre mais amplo e profundo do que o do comum dos mortais, e de novo trazem a ordem ao mundo conturbado. Porém, como podem ser benéficos, também podem ser nocivos, ambigüidade que corresponde a dos próprios santos e é peculiar à ordem do mundo: pois até o padrinho celeste não se volta às vezes contra seu devoto? (25) Os conhecimentos de curandeiros, de feiticeiros, de taumaturgos também têm limites, eles podem se enganar como qualquer um.

O sitiante tradicional está convencido de que a ignorância é causa de toda ação nociva, de todo pecado, - de todas as atividades que desencadeiam poderosas forças contrárias, ou que despertam a ira dos padroeiros celestes. Tradiçäo, experiência, saber permitem agir com maior segurança, embora o risco subsista sempre. Se o sitiante sofre reveses, é porque conhece mal o vasto mundo difuso que o cerca. Todavia, não manifesta diante dele nem medo, nem angústia: imensidade e indefinição fazem parte da ordem natural das coisas. Curioso diante de tudo quanto ignora, gosta de ouvir falar de novidades e está pronto a dividir seu próprio saber com os outros, sob a forma de anedotas, de historietas, de ditados, de provérbios. Pergunta, reflete em voz alta, especula ingenuamente, procura ir mais fundo na compreensão do mistério universal, que acredita ser regido por uma lei de participação reciproca: tudo está interligado, tudo alcança uma explicação natural e sobrenatural, porém sempre relativa.

(24) EEnviados divinoss e esantoss que percorrem as vezes o melo rural podem viver cercados de concubinas e manlfestar perversóes, sem que isto afete seus poderes sobrenaturais. Ao contrário, o comportamento excepcional e prova de suas poderes sobrenaturais. Á contrário, se entregam sem risco a atividades que săo proibidas aos mortals, sob pena de terrivels castigos. Pereira de Queiroz, 1957 e 1965 a).

(25) Conta-se que um devoto de $\mathrm{S}$. Jorge, vendo de longe uma onca, Interpela o santo padroeiro: eMeu S. Jorge, a onca vem p'rá riba de mim. Si mecé ê por mim, que eu mate ela de um górpe. Si mecé é contra mim, que ela me máte sem do. Mas si mecè năo se metê, flque de fora que mecê val về a briga mais linda entre bicho e home que mece pode magina!s 
"Quem pode afirmar qualquer coisa"? Esta pergunta está sempre na mente do sitiante tradicional. Nenhuma explicaçāo lhe parece definitiva, já que por toda a parte existe o desconhecido e que o saber humano é limitado. Está cercado pelo desconhecido: o desconhecido da extensão geográfica, encerrando o mistério dos países longíquos, das naçōes estrangeiras e diferentes; o desconhecido da extensão social, que contém aspectos heterogêneos, como o da vida nas cidades; o desconhecido do outro mundo, onde lado a lado se reúnem a realidade quotidiana do padrinho celeste, sempre presente em seu altar, e a existência invisivel do paraíso. Vive assim à beira do desconhecido e na iminência da partida, seja para outras regiōes em que a vida talvez se torne mais agradável, seja para o Reino Celeste - pois o apelo divino pode vir a qualquer momento. $O$ desconhecido faz parte do sistema em que vive o sitiante tradicional, o desconhecido é normal; para ele, que não é torturado pelo mistério das coisas nem pelo terror do sagrado, mistério e sagrado pertencem ao mesmo mundo da realidade quotidiana.

A análise que acabamos de fazer mostra que, por meio da parentela e do grupo de vizinhança, o sitiante tradicional forma a idéia da sociedade e do mundo em que vive. Sua existência permanece ligada a estas duas realidades primordiais ,em que está inserida a familia conjugal, fonte de seus rendimentos econômicos, e que the servem de cenários complementares. Assim, a percepçăo que tem do espaço não parece ultrapassar seu ambiente direto, e seria assim definida como "egocêntrica", um dos diversos tipos de percepção definidos por Georges Gurvitch. A noção geográfica e social do bairro se forma a partir do conhecimento da localização da capela, ponto central do grupo de vizinhança, e dos lugares habitados pelas familias que compōem o grupo. Relaçōes familiares, relaçōes de trabalho, relaçōes religiosas constituem as coordenadas que orientam a percepçāo do sitiante, que parece ser então também "concêntrica", pois gira em torno de um pequeno núcleo central.

Todavia, se à primeira vista estas sāo as qualidades da percepçāo do nosso sitiante tradicional, não é menos verdade que as relaçōes com o grupo de parentes disperso no espaço favorecem também uma percepção mais vasta, - a da regiăo, do país, da sociedade rural, de que o bairro é parte integrante. Alguns membros da familia partiram para zonas longinquas, para outros estados, para as cidades; todas estas localizaçōes diversas formam um conjunto que é "o mundo", cujos contornos porém permanecem sempre vagos. Nāo se sabe nunca muito bem até onde se estende o grupo de vizinhança nem quanto pode ele aumentar, já que acolhe constantemente familias vindas de fora. A parentela estando disseminada sobre um território vasto, nāo se sabe que configuraçāo toma exatamente, tanto mais que os laços de compadrio the permitem estender-se indefinidamente. Não se sabe também quais são os limites entre natural e sobrenatural, que coexistem sem descontinuidade. O espaço tende, pois, a parecer "difuso", sem contornos precisos. 
A abertura do bairro a todos que nele quiserem se instalar; a multiplicação indefinida dos bairros a partir de uma célula mãe; a imprecisão dos limites que deixa as familias periféricas na indecisão quanto à sua integração neste ou naquele bairro, constituem o contrário da configuraçāo precisa e fechada de um grupo social egocêntrico, voltado sobre si mesmo, limitado em seus contornos. O fato da parentela se espalhar no espaço geográfico impede o desenvolvimento de uma noção puramente concêntrica, a partir do núcleo familiar; a familia conjugal, geograficamente localizada, não é senão um elo da cadeia dos parentes, e sua importância é sobretudo econômica; ao nivel das relações sociais, a parentela vem em primeiro lugar, uma parentela definida pelos laços de sangue, pelos laços de aliança, pelos laços de compadrio, cujos limites permanecem tão imprecisos quão imprecisa é a extensão geográfica. Por outro lado, o bairro nāo é percebido como único. Festas religiosas e romarias colocam os sitiantes em contacto com outros grupos semelhantes aos dele, que reconhecem nāo apenas como homogêneos, mas também como iguais. Se deixar seu bairro, o sitiante sabe que encontrará outro em que poderá se integrar. O espaço tende, por outro lado, a ser percebido como difuso e descentralizado, e nāo apenas como egocêntrico e concêntrico, como parecia à primeira vista.

Constata-se habitualmente entre nós que toda distância geográfica parece curta ao sitiante. conhecida a anedota do citadino que pergunta ao sitiante a que distância mora o vizinho: "- Ali pertinho", responde o interrogado, utilizando a mímica tradicional: distendendo o lábio inferior tanto quanto possivel na direção que quer indicar. 0 citadino pōe-se a caminho, sobe e desce colinas, encontra outro sitiante, faz a mesma pergunta, recebe a mesma resposta com a mesma mímica. Depois de uma hora de caminhada, chega, extenuado, à casa do vizinho... "ali" pertinho, distante algumas "léguas de beiço". As léguas não têm medida fixa no meio rural brasileiro, variam conforme as regiōes, conforme as localidades, conforme as pessoas... Toda distância geográfica parece pequena ao sitiante tradicional porque é avaliada segundo as relaçōes sociais estreitas de parentesco e vizinhança; dir-se-ía que vê o mundo em miniatura. Os laços de parentela e de vizinhança lhe permitem viver numa extensão vasta, sem ser aniquililado por ela; tais laços anulam a tendência à amonia que resultaria de um povoamento rarefeito como o nosso, disseminado sobre um território muito extenso.

Além disso, se o sitiante não conhece a distância geográfica a não ser de modo imperfeito, não tem também noçāo muito exata da distância social, principalmente da que existe numa sociedade de classes. Vive num grupo social igualitário e sente-se levado a considerar todos os indivíduos como pertencendo ao mesmo nivel social que é o seu. A consciência que tem da própria dignidade, de seu valor pessoal é muito viva. Em sua visāo, a sociedade perde a dimensāo vertical dada pela superposição das classes sociais; não conserva senão um nivel, é "achatado". O que não o impede de ter consciência nitida da diferença que existe entre ele e o citadino; mas trata-se 
então de duas soceidades diversas, paralelas, que se interpenetram e são complementares. Năo as concebe como superpostas (26).

A parentela e o grupo de vizinhança, em sua imprecisão e fluidez, servem de quadros de referência a partir dos quais o sitiante percebe a extensão do mundo que o cerca, porém a própria qualidade das relaçōes internas peculiares a esses dois grupos sociais - relaçōes que aproximam os individuos em lugar de separá-los, relaçōes estreitas, diretas, pessoais, afetivas - fornecem também a definição dos espaços e das distâncias. Pois não é ínfimo o valor de dia de caminhada, quando se trata de visitar parentes que os laços familiares tornam muito próximos?

Chegamos assim à constatação de que o espaço percebido pelo sitiante tradicional é certamente ambíguo. Em primeiro lugar, é pouco diferenciado. Espaços geográficos, sociais, sobrenaturais formam um todo inseparável e as mesmas técnicas de abordagem - consubstanciadas pelas relaçōes pessoais e afetivas - săo empregadas para dominá-los. Devido a isso, o espaço parece ao mesmo tempo difuso e restrito, concêntrico e descentralizado. Esta ambigưidade é causada pela oposição entre os caracteres dos espaços, que na verdade são vastos e difusos, e os instrumentos de que dispōe o sitiante para percebê-los e captá-los, isto é, as relaçōes de vizinhança e de parentesco. Assim sendo, a noçäo de espaço do sitiante só pode nos parecer ambigua, contraditórias, afastada do real, pois vivemos num outro universo dominado pela especialização e pela quantificaçāo. Uma vez que a técnica utilizada pelos sitiantes tradicionais para a percepçăo do espaço nāo é adequada para dar uma noçăo próxima do real, é possivel dizer que os sitiantes tradicionais vivem num mundo ilusório e facticio, criado pela disparidade entre os instrumentos de percepção de que dispōem e a realidade? Certamente não, pois sua percepção do espaço lhes é útil de um ponto de vista operacional; guiados por ela, agem satisfatoriamente para chegar a seus fins; a noçāo de espaço de que dispōem não os ilude nem decepciona, não os desorienta.

Os citadinos não estāo longe de pensar que o Brasil é perseguido pela "maldiçāo do espaço": tudo é grande demais neste pais e as medidas racionais para dominar completamente tāo vasta extensāo se revelam em geral impraticáveis porque demasiado dispendiosas; forma-se assim um sentimento de impotência e de desânimo diante de empreendimentos que parecem impossiveis. Ora, o sitiante tradicional năo fica nem desanimado, nem perdido, nem angustiado diante da extensāo contraditória que consegue captar, e desenvolve mesmo um sentimento de otimismo. Não vê o espaço como ameaçador; ele encerra, ao contrário, a esperança de melhoria de vida, de aumento de bem-estar. A vasta extensāo geográfica, a parentela dispersa e difusa sāo indispensáveis ao gênero de vida, ao equilibrio econômico do sitiante tradicional. A primeira encerra as novas terras que vão se substituindo às já

(26) Pereira de Quelroz, 1965 b. 
cultivadas e cuja fertilidade lhe permite viver segundo um nivel econômico ótimo definido pela tradição. A segunda garante-lhe que nāo será nunca um indivíduo abandonado.

$\mathrm{E}$, pois, quando o espaço começa a lhe faltar que a visão otimista do mundo do sitiante tradicional tende a se desfazer. Com efeito, em várias regiōes do Brasil, a multiplicação das grandes monoculturas e da criação extensiva desaloja os antigos ocupantes; a terra de melhor qualidade passa a ser ocupada pelas grandes plantaçōes, e o pequeno lavrador que consegue permanecer na região, conservando sua roça, sofre prejuizos que acarretam a decadência. Não pode mais viver segundo as relaçōes ecológicas tradicionais; deve, custe o que custar, cultivar sempre a mesma terra, cuja fertilidade vai decrescendo; não conhece fertilizantes e não teria também meios para utilizá-los. Chega o momento em que, forçado a abandonar seu gênero de vida, torna-se um assalariado agrícola nas grandes plantaçōes vizinhas, ou emigra para as cidades, onde vai trabalhar como mão-de-obra: em qualquer dos casos, não pertence mais à antiga sociedade de sitiantes independentes, mas se integra no grau mais baixo de uma sociedade de classes de tipo urbano. Nas zonas invadidas pelas grandes monoculturas ou pela indústria, o otimismo do sitiante se desfaz; cercado de todos os lados pelos grandes proprietários ou pela vida citadina, pode ser levado a verdadeiros atos de desespero (27).

O êxodo dos sitiantes para as cidades, que se acelerou extraordinariamente no decorrer dos últimos anos, ao mesmo tempo que a grande propriedade devorava mais e mais regiōes ainda inexploradas do pais, constitui talvez uma tentativa para reencontrar, em plano diferente, a imensidade perdida dos espaços tradicionais. A cidade grande, com inúmeros empregos, parece oferecer ao sitiante um sucedâneo do antigo espaço vasto, difuso, inesgotável; pode-se ali achar formas as mais diversas de ganhar a vida, enquanto no meio rural as possibilidades de trabalho são limitadas. Na cidade, o sitiante tradicional nāo pode mais mudar de "habitat", porém pode mudar de emprego e procurar obstinadamente encontrar um que o satisfaça. As pesquisas sobre a adaptaçāo dos habitantes do meio rural às metrópoles brasileiras mostraram a existência de um "turn over" extraordinário; a mudança de emprego é freqüente e habitual (28). Nâo se tratará de uma transposição, ao espaço urbano, da maneira de compreender o espaço rural?

Por imperfeitas que sejam as noçóes do sitiante tradicional em matéria de distância e de espaço, tanto no plano geográfico quanto no plano social, não deixam de ser eficazes do ponto de vista operacional. A noção de espaço do sitiante corresponde ao que espera; sua interpretação é válida dentro do contexto social a que pertence. Quando o espaço rural se modifica, quando

(27) Carlo Castaldi e outros, 1957.

(28) Brada Lopes, 1957; Cardoso, 1960 e 1961. 
se estreita, fragmentado em espaços muito pequenos pela introđução da grande propriedade na regiāo em que habita, o sitiante passa a se sentir desorientado, perdido; e isso porque a extensão que conhecia se transformou. A comparaçăo do espaço percebido pelo sitiante com o espaço que nós percebemos, mostra bem a existência de uma variabilidade de percepçōes. Ora se percebem espaços diversos porém integrados uns nos outros, de tal maneira que podem ser dominados por um só instrumento, pois com um só instrumento - sitiante tradicional domina os espaços geográfico, social e sobrenatural; percebem espaços diferenciados, separados, exigindo cada qual um instrumento particular para ser captado - é o que acontece com nossa noção de espaços especializados. A variabilidade das noçōes de espaço está, pois, em correlasāo com diferentes tipos de sociedade, como afirmara Georges Gurvitch.

Dissera também este autor que os espaços são sempre inseparáveis da percepção que os capta; compreendia-os, então, como extremamente variáveis, já que são diversas as perspectivas que permitem tomadas de consciência. Todavia, insistiu também sobre o caráter único dos espaços. Ora, a análise que acabamos de fazer demonstrou a existência de três espaços diversos, embora misturados e confundidos no universo do sitiante tradicional: - espaço geográfico, o espaço social, o espaço sobrenatural. Num outro tipo de sociedade, podem-se separar e se tornar inteiramente distintos. Assim, tais espaços formam um conjunto pouco distinto, que se dissociará talvez um dia em parcelas diversas, como se verifica quando se opera a transformaçăo do espaço indiviso que conhece o sitiante tradicional, em espaço dividido; e tal se dá seja pela introdução da grande propriedade no espaço geográfico, seja pela introdução da grande cidade no espaço social. 0 espaço é, pois, variável em sua maneira de ser; sua diversidade não decorre apenas da diversidade de meios de percebê-lo e captá-lo; decorre também de caracteres que the são próprios, o que leva a concluir que o espaço se modifica à medida que é trabalhado e construido pelo homem. Portanto, a ambigüidade que se pode atribuir à imperfeição dos instrumentos de captação, como haviamos feito de inicio, pode ter raizes mais profundas, resultando talvez também do fato do espaço ser transformável e, em suas modificaçōes, tomar aspectos ambiguos e contraditórios. Ao contrário do que mostrara Georges Gurvitch, parece-nos que a qualidade do espaço é variável, que este não é forçosamente único.

Mas todas estas divergências entre nossa maneira de pensar e a do mestre que pela primeira vez tentou uma sociologia da percepção do espaço, nāo săo senāo consequência da falta de estudo destes problemas, e nāo invalidam tudo quanto apontou. A utilidade das noçōes que nos transmitiu é patente, permitindo abordar a mentalidade do sitiante tradicional por uma perspectiva ainda nāo focalizada. Dizia Georges Gurvitch que, ao estudar a percepşāo do espaço de ângulo sociológico, nāo desejava senāo mostrar a existência de "um vasto dominio ainda nāo desbravado, em que as pesqui- 
sas empiricas se impōem". (29). A análise que aqui apresentamos demonstra a complexidade e o grande interesse da nova abordagem que sua inteligência, tão extraordinariamente dotada para as descobertas, indicou aos pesquisadores.

\section{B I B I I O G R A F I A}

BRANDKO LOPES, Juarez R. - A flxacăo do operárlo de origem rural na indústrlas. Educacão Ciôncias Sociais, ano II, vol. 2, n.॰ 6, Rlo de Janelro, novembro de 1957.

Candido, Antonlo - Os Parceiros do Rio Bonlto. Llvrarla Martins Editora, S. Paulo, 1964.

CARDOSO, Fernando Fenrique - eProletarlado e Mudanca Social em S. Paulos. Soclologla, vol. XXII, n.॰ 1, S. Paulo, marco 1960.

CARDOSO, Fernando Henrique - ele prolétarlat brésllien: situation et comportements. Sociologle du Travall, 3.0 année, n.० 4, Parls, outubro-dezembro 1961.

Castaldi, Carlo e outros - Estudos de Soclologia e História. Ed. Anhambl, S. Paulo, 1957.

GARCIA FUKUI, Lla Freltas - eLes rélations mère-enfants parml les paysans de statut soclo-économlque Indépendant au Bréslls. Carnets de Lenfance, Fonds des Nations Unies pour l'Enfance, n.॰ 10, Paris, Junho-julho 1969.

GURVITCH, Georges - «Les varlations des perceptions collectives des étendues». Cahiers Internationaux de Soclologie, vol. XXXVII, Parls, 1964.

GURVITCH, Georges - La Sociologio de la Perception des etendues. Curso ministrado na Ecole Pratique des Hautes Etudes, VI.• Section, Parls, 1963-1964.

MARC, Alfred - Le Brésll. 2 vols., Parls, 1889.

MULLER, Nice Lecocq - sitios e sitiantes no Estado de São Paulo. Faculdade de Fllosofia, Clenclas e Letras, U.S.P., 1951.

PEREIRA DE QUEIROZ, Maria Isaura - La Guerre Sainte an Brésil: Le Mouvement messlanique du Contestado. Faculdade de Fllosofla, Cienclas e Letras, Universldade de $S$. Paulo, 1957.

PEREIRA DE QUEIROZ, Maria Isaura - Soclologla - Folclore: A Danca do 8. Goncalo num Povoado Bahlano. Livrarla Progresso Ed, Bahla, 1958.

PEREIRA DE QUEIROZ, Maria Isaura - eDésorganisation des petites communes brésillenness. Cahlers Internationaux de Sociologie, vol. XXVIII, Parls, 1960.

PERGIRA DE QUFIROZ, Maria Isaura - cOs penitentess. Suplemento Llteráio, eO Estado de S. Paulon, 29-9-1961.

(29) Georges Gurvitch, 1964, p. 108. 
PEREIRA DE QUEIROZ, Maria Isaura - sUma categorla rural esquecidas. Revista Brasillense, S. Paulo, marco 1963 a.

PEREIRA DE QUEIROZ, Marla Isaura - eMouvements messlanlques et dévéloppement économique au Bréslls. Archives de Sociologle des Regllons, n. 16, Parls, $1963 \mathrm{~b}$.

PEREIRA DE QUEIROZ, Maria Isaura - o Messianismo no Brasil e no Mundo. Dominus Ed., S. Paulo, 1965 a.

PEREIRA DE QUEIROZ, Marla Isaura - eLes classes soclales dans le Brésil actuels. Cahlers Internntionaux de Soclologlo, vol. XXXIX, Paris, 1965 b.

PEREIRA DE QUEIROZ, Maria Isaura - eBairros Rurals Paullstass. Revista do Museu Paulista, Nova Sérle, vol. XVII, S. Paulo, 1967.

PEREIRA DE QUEIROZ, Marla Isaura - cLe paysan brésllien traditlonnel et la perception des étenduess. Terspectives de la Sociologie Contemporaine (Hommage a Georges Gurvitch). Presses Universitaires de France, Paris, 1968.

PEREIRA DE QUEIROZ, Marla Isaura e GARCIA FUKUI, Lla Freltas - $<$ sitlante brasllelro e as transformacóes de sua situação sócio-economlcas. Cadernos, Centro de Estudos Rurals e Urbanos, n.॰ 1, ano 1, S. Paulo, 1968.

REDFIELD, Robert - The Primitive World and its Transformations. Cornell University Press, U.S.A., 1953. 